\title{
Die prediking oor die eindoordeel
}

I W C van Wyk

Hervormde Teologiese Opleiding

Tydelik-deeltydse dosent: Departement Dogmatiek

en Christelike Etiek (Afd A)

Universiteit van Pretoria

\begin{abstract}
Preaching on the last judgemient

This article deplores the fact that the theologumenon 'last judgement' has become a museum piece. It seeks to stimulate a new debate on this topic. The author is convinced that this theologumenon is a central topic of the Jewish-Christian religion and should therefore be actualised in such a way that it again can become part of the living faith of the church. The author enters into discussion with Moltmann about God's actions in this world, with Pannenberg about the criterion of the judgement and with Kung about eternal punishment.
\end{abstract}

\section{INLEIDING}

Rudolf Bohren (1986:556) het in die nawoord tot die vierde uitgawe van sy Predigtlehre die volgende belangwekkende uitspraak gemaak: 'Wenn ich heute die Prediglehre neu schreiben würde, würde ich das Gericht weit mehr in den Vordergrund stellen'. Die redes wat Bohren vir hierdie uitspraak aanvoer, behoort ook onder die aandag van die Nederduitsch Hervormde Kerk te kom, aangesien Hervormers stadig maar seker besig is om ook dieselfde fout te maak deur die gerig te verswyg. Bohren (1986:555) meen dat die eietydse prediking die geheim verklap dat die predikers nie meer die 'vrees van die Here' ken nie. Die redes is dat die hedendaagse prediking by die empirie begin - verskuil agter die linguistiek, semantiek en retoriek. Gelyktydig hiermee is daar die emosionele teenkanting teen die dogmatiek. Die dogmatiek (veral die kerklike dogmatiek) word vermy, aangesien 'n ander dogma, die binetariese dogma van aanvraag en aanbod met die aanloklike belofte van sukses daarby, hoogty vier. Daar word by die empirie begin, aangesien die hoofbelangstelling nie meer rondom die waarheid nie, maar rondom die 'sukses' sentreer. Dit gaan daarom vandag om dit wat 'tuiskom', omdat dit wat kan 'tuiskom' die norma normans van die preekleer geword het. God, wat ook die verhewe Regter is, laat Hom ongelukkig nie 'tuisbring' nie. Ons het alreeds vanuit hierdie perspektief genoeg rede om ons met die prediking van die eindoordeel besig te hou. 
Volgens Hebreërs 6:2 geld die eindoordeel as een van die mees basiese leerstukke van die Christelike geloof. Saam met die leerstukke oor die bekering van 'n verkeerde lewenswyse, die geloof in God, die doop, die handoplegging en die opstanding van die dooies is die leerstuk oor die eindoordeel die fondament van die Christelike geloof. Dit is daarom eksegeties gesien ondenkbaar dat die leer oor die eindoordeel uit die Christelike leer en lewe weggelaat kan word. Sonder hierdie fondament kan die huis nie staan nie. Om hierdie rede mót daar weer sistematies oor hierdie saak nagedink word en mót daar weer oor hierdie tema in ons gemeentes gepreek word.

Intensiewe navorsing en aktuele prediking oor die eindoordeel deur die ouer kerke sal die sendingwerkers en jonger kerke in Afrika ook ten dienste wees. John Mbiti (1985:161) wys daarop dat Afrika nie so iets soos 'n eindoordeel ken nie. Dit is daarom ook dringend noodsaaklik dat hierdie tema aan Afrika bekend gestel moet word.

\section{DIE REFORMATORIESE PREDIKING OOR DIE EINDOORDEEL}

Binne die Reformatoriese tradisie was die prediking oor die eindoordeel 'n vanselfsprekendheid (Peters 1967; 1984:199-238). Dit was 'n vanselfsprekendheid aangesien die Reformatore die volle waarheid van die Skrif verkondig het. Hierdie volle waarheid word aan die hand van eksegetiese insigte in die dogmatiek gesistematiseer en in die belydenisse kernagtig saamgevat. Dogma, belydenis en prediking het vir die Reformatore 'n onlosmaaklike samehang gevorm en daarom is daar in die prediking aan die hand van hulle dogmatiese insigte, soos dit onder andere in hulle uitleg van die Apostolicum na vore gekom het, gepreek.

Martin Luther het besondere moeite gedoen met die die uitleg van die Apostolicum - en daarom ook met die kerk se belydenis aangaande Jesus Christus se wederkoms wat oordeel oor lewendes en dooies veronderstel. In sy Belydenis van 1528 het Luther aandag aan beide aspekte van die eindoordeel gegee, naamlik die van redding en die van verwerping. In die geskrif Vom Abendmahl Christi (1528) kon hy daarom die volgende skryf:

Am letzten gläube ich die Auferstehung aller Toten am Jüngsten Tage, beide der Frummen und Bösen, daB ein iglicher daselbs empfahe an seinem Leibe, wie ers verdient hat, und also die Frummen ewiglich leben mit Christo und die Bösen ewiglich sterben mit dem Teufel und seinen Engeln.

(WA 26, 509, 13) 
Deur albei waarhede van die eindoordeel te beklemtoon, het Luther hom van die laatMiddeleeuse uitleg van die eindoordeel gedistansieer en terugbeweeg na die tradisionele uitlegtradisie wat op Irenaeus en Tertullianus voortgebou het. Tog het Luther in sy eie gemoed nie tevredenheid oor hierdie posisie-inname gehad nie. Volgens Luther bring die beklemtoning van die verwerpingsgedagte té veel onsekerheid in die gemoed van die gelowige mee. Hy het op die ou einde tog verkies om eerder aan woorde soos dié van Johannes 5:24 vas te hou aan die hand waarvan die gelowige sekerheid ten opsigte van sy posisie by die eindoordeel kon kry. Dit beteken dat Luther, na 'n worsteling, sy rug op die laat-Middeleeuse prediking gekeer her. In sy Klein Kategismus (1529) het hy die klem in sy uitleg doelbewus eensydig net op die vreugdevolle verwagting van die gelowige se verlossing van alle chaosmagte geplaas. In sy Groot Kategismus (1529) het hy weer doelbewus 'n ander perspektief eensydig beklemtoon, naamlik die feit dat die eindoordeel die voleinding van Christus se heerskappy is (kyk Peters 1991: 166).

Die laat-Middeleeuse prediking oor die eindoordeel was die produk van 'n lang dogmenontwikkeling binne die Roomse Kerk. Die basis van hierdie dogmenontwikkeling gaan terug na Irenaeus se Adversus haeresus. Irenaeus het 'n baie ewewigtige standpunt oor aanname en verwerping, gerig en genade gehad:

Dieselfde God wat oordeel, is ook die Vader wat tot heil roep; Hy skenk aan die een die ewige lig en laat diegene wat nie 'n bruilofskleed aan het nie, in die buitenste duisternis werp. Dieselfde God, die Vader van onse Here wat die profete gestuur het, roep weens sy oneindige goedheid wel onwaardiges, sien egter daarna om dat die geroepenes wel 'n bruilofskleed aan het, wat vir die bruilof van sy Seun, gepas is.

(Adv haer IV, 36, 6)

Augustinus het hierdie spanning tussen gerig en genade gehandhaaf. Hy het hierdie spanning egter op Christus as die Regter en Voorspraak toegespits. Aan die een kant leer hy: die persoon wat ons verwag om eenmaal ons Regter te wees, is tans ons Voorspraak by die Vader - daarom het ons rede tot hoop. Aan die ander kant het hy gereeld die blywende vrees vir die oordeel onderstreep (kyk Peters 1991:168). Volgens Augustinus behoort gelowiges ook hierdie oordeel te bly vrees en daarom moet hulle só lewe dat hulle deur hulle lewe die doop komplementeer. Op hierdie wyse ontvang hulle uiteindelike die seën van die Here. 
In die naam van Augustinus het 'n persoon of persone, bekend onder die naam 'pseudo-Augustinus', in 'n versameling corgelewerde preke die gerigsmotief binne die Roomse Kerk geweldig versterk (kyk Peters 1991:168 vir volledige verwysings). Hierdie invloed was só sterk dat Thomas van Aquino byvoorbeeld 'n totale gebrek aan die vreugdevolle verwagting van die eindoordeel geopenbaar het. Die verlossingsdimensie wat onlosmaaklik deel van die gerigsmotief is, het by Thomas totaal ontbreek (Pesch 1967:838). Hy het in sy Credo-uitleg op die redes vir die vrees van Christus gekonsentreer (kyk Peters 1991:168 vir die nodige verwysings). Teenoor hierdie redes om Christus te vrees (sy wysheid, mag, onveranderlike geregtigheid en heilige toom) het hy vier heilsmiddele (goeie werke, die bieg, die aalmoese en die liefde tot God en die naaste) gestel. Die konsekwensie hiervan vir die prediking was dat daar verkondig is dat daar nou nog tyd vir genade is, aangesien daar by die wederkoms geen ruimte vir genade sal wees nie omdat die gerig gerig is en nie genade nie. Hierdie teenstelling van nou genade - dan die oordeel, was ook kenmerkend van die prediking in die tydperk na Thomas.

Dit was hierdie prediking van 'vandag is Christus die Barmhartige - later gaan Hy die strenge Regter wees', wat Luther tot twyfel en ook tot sy sogenaamde 'toringervaring van bevryding' gedryf het. Hy kon nie aanvaar dat die motief van die eindoordeel oor die werke die motief van die regverdiging deur die geloof so radikaal kan ondergrawe nie. Hy het van sy vorige uitsprake ${ }^{1}$ or die eindoordeel herroep en dit anders begin uitle. In teenstelling tot die nuwe-Protestantisme wat die hele gerigsmotief verwerp het (hierop kom ons weer terug), het Luther streng aan die totaliteit van die Bybelse boodskap vasgehou, maar 'n ander klem as die Roomse teoloê begin lê. Hy het die klem verplaas na wie Christus is. Christus Jesus, die kind van Bethlehem, is dieselfde persoon wat sal kom om die eindoordeel te voltrek. Alhoewel Hy dus ons Regter gaan wees, bly Hy ons Voorspraak en ons Regshelper. Hy het dit op dramatiese wyse as volg in 'n preek van 16 April 1533 uitgespel:

Ob er wohl ein Richter sein wird, so soll ers doch auch mir zu Trost und Heil sein also, daß er mich schütze widder meine Feinde und die verdamme, die nicht gläuben wollen noch ihn für Herrn halten, also daB man kurzumb allen Zom, Urteil und Strafe wegwerfe von uns auf seine Feinde, den Teufel und alle seine Pfeil und widder dein eigen böse Gedanken von Christo.

(WA 37, 51, 21) 
Volgens Luther mag daar daarom nie 'n teenstelling gemaak word tussen vandag/hier en eendag/daar nie. Wie vandag hier Christus as sy Heer aanneem, sal eendag daar aangeneem word. Wie vandag hier egter Christus verwerp sal eendag daar ook verwerp word (dit het hy in 'n preek alreeds op 11 Mei 1525 oor 1 Tess 4:15 gesê - kyk WA $17 \mathrm{I}, 221,11$ ). Die belangrike, in teenstelling met Thomas, is dat die eindoordeel volgens Luther daarom 'n dag van vreugde vir die gelowiges sal wees, aangesien dit die dag van hulle erbarming gaan wees. Om hierdie rede het hy sy gemeentelede ook gereeld opgeroep om te bid vir die wederkoms en hulle verseker dat hulle met opgehewe hoofde (Luk 21:28) hierdie dag tegemoet kan gaan.

Waar Martin Luther die vreugde en hoop van die gelowige in die aangesig van die eindoordeel beklemtoon het, het Johannes Calvyn weer die klem op die vreugdeloosheid en hooploosheid van die ongelowige by die eindoordeel geplaas. Calvyn het die klem op grond van sy dogmatiese insigte op hierdie saak geplaas. Hy was nie 'n voorstander van dogmenprediking nie, tog wel 'n uitstaande eksponent van dogmenbehandeling in die prediking. Hy het verplig gevoel om sy dogmatiese insigte in die prediking ter sprake te bring (kyk Van der Vegt [s a]:20-21). Hy het daarom ondubbelsinnig gereeld in sy prediking op die spekulatiewe vraag, of 'n ongelowige salig kan word, geantwoord dat so iets nie moontlik kan wees nie (Inst IV, 1, 5 en Kommentaar op Hand 9:6 = CR 48:204). Iemand wat nie die prediking hoor en daarom nie tot bekering en geloof kom nie, kan nie by die eindoordeel gered word nie. Om hierdie rede het hy by die belydenis van die vroeee kerk, naamlik dat niemand buite die kerk salig kan word nie, aangesluit (Inst IV, 1, 4). Daar moet onthou word dat die prediking van Calvyn uiteindelik gerig is op die eer van God (Van der Vegt [s a]:13-17). God ontvang, volgens Calvyn, sy eer wanneer sy Woord verkondig word en dit gehoor en geglo word. Teen hierdie agtergrond kon hy dan ook die radikale uitsprake maak, wat hy wel gemaak het. Hy het onder andere in sy kommentaar op 2 Korinthiërs 2:15 (CR 50:34) gesê dat die eer van God juis gedien word wanneer die regverdige verdoemenis aan die verworpenes (ongelowiges) verkondig word.

Dit beteken nie dat Calvyn met bangmaakprediking besig was nie. Hy het wel verplig gevoel om die ongelowiges die waarheid mee te deel, maar dan sonder om die gelowiges te verwar. In sy Kategismus van 1545 (kyk CR 6:37-38) het hy op die voetspoor van Luther soos volg op die vraag geantwoord of die gelowige die eindoordeel moet vrees: Nee, aangesien ons voor niemand anders as ons Voorspraak gaan verskyn nie. Calvyn het hierdie dubbele waarheid rondom die eindoordeel treffend in 'n preek oor 2 Tessalonisense 1:8-10 saamgevat. Hy het onder andere die volgende uitspraak daarin gemaak: 
En dit is een leer, die in de Schrift veel verbreid is, dat nl. onze Heere deze twee zaken met elkander verbindt: dat Hij komen zal om sich aan $\mathrm{Zijn}$ vijanden te wreken en om die Zijnen te bevrijden; dat Hij komen zal om Verlosser te zijn voor hen, die Hem hebben gediend en geëerd, en om ten verderve te brengen en ten gronde te richten, die zich tegen Hem en $\mathrm{Zijn}$ woord hebben verhard.

(Calvyn, in Van der Vegt [s a]:203)

Volgens Calvyn is die eindoordeel dus wel 'n verskriklike gedagte. Dit is egter net vir die ongelowiges 'n verskrikking, aangesien die kriterium of maatstaf van die eindoordeel die geloof - of dan die ongeloof - in die evangelie van Jesus Christus is. Dit is juis hierdie waarheid van die Skrif wat vandag nie meer algemene instemming geniet nie.

\section{HUIDIGE TENDENSE RONDOM DIE LEER VAN DIE EINDOORDEEL}

Die tema van die eindoordeel was minstens tot aan die begin van die $19 \mathrm{e}$ eeu 'n baie lewendige en aktuele tema. As bewys hiervan kan aan die talle prominente kunstenaars herinner word wat hierdie tema as van groot persoonlike relevansie geag het. Mozart was een van die kunstenaars wat ernstig met die eindoordeel geworstel het. Vanuit sy Requiem, wat hy ongelukkig weens sy vroeë dood in 1791 nie kon voltooi nie, is dit duidelik hoe die eindoordeel in daardie tyd verstaan is. Die eindoordeal (as die dag van wraak en trane) het by Mozart vrees ingeboesem aangesien dit die dag sal wees waartydens daar voor God die streng $\cdot$ Regter om genade gesmeek sal word. In die sequence gedeelte van die Requiem word die volgende gesing:

Dies irae

Dies irae, dies illa, solvet saeclum in favilla: teste David cum Sibylla.

Quantus tremor est futurus quando iudex est venturus, cuncta stricte discussurus.

Quid sum miser tunc dicturus? quem patronum rogaturus, cum vix justus sit securus? 
Die gedagte van die eindoordeel as die dag wat vrees inboesem is vandag egter voorlopig iets van die verlede ${ }^{2}$. Dit is egter nie net hierdie voorstelling van die eindoordeel wat nie meer aanvaarding geniet nie, maar die gedagte van die eindoordeel as sodanig het 'n museumstuk geword (Amelung 1984:492-493; Lochman 1993). Hiervoor kan verskillende redes aangevoer word. Die een rede wat aangebied word, is dat die Westerling van hierdie eeu aan 'n totale verlies van eskatologiese visie ly (Brunner 1966:125). Omdat sy visie nie meer op die toekoms (veral 'n verre toekoms) gerig is nie, verwag hy ook nie meer so iets soos 'n eindoordeel nie. Wanneer mense nie meer 'n eskatologiese bewussyn het nie, het dit weinig sin om teologies tyd en energie op eskatologiese temas te mors.

'n Volgende rede is dat die nuwe Protestante soos Emanuel Hirsch (of 'n mens dit nou wil weet of nie) meer invloed uitgeoefen het as wat ooit besef word. Hirsch (1923:208) het meegehelp om die gedagte te vestig dat God nie wesenlik Regter kan wees nie, aangesien dit God se primêre begeerte is om met sy kinders gemeenskap te hê. Die 'gerig' is daarom hoogstens 'n middel van loutering tot volle gemeenskap. Met hierdie basis is dit dan ' $n$ argumentatiewe noodwendigheid dat die verlossing van almal, die apokatastasis, vir hom die hoogste gedagte van die geloof is (Hirch 1923: 223). Wanneer geloof tot die persoonlike redding (ook nog van almal) ingeperk word, word die maatskaplike ontwikkelingsgang maklik as vrug van die evangelie verwar ${ }^{3}$. Die rede hiervoor is eenvoudig: wanneer 'n samelewingsorde 'n religieuse selfverstaan produseer wat aan elke lid van daardie samelewing ewigheidswaarde toeken, is dit 'n noodwendigheid dat só 'n samelewingsorde religieuse legitimasie sal geniet.

Die burgerlike kultuurwêreld van middel-Europa, wat mense soos Hirsch en die ander kultuur-Protestante vóór hom teologies wou legitimeer, het sedert die Franse rewolusie stelselmatig verkrummel. Die ondergang van instellings wat die feodale stelsel opgelewer het, en die daarmee gepaardgaande onsekerheid oor die toekoms, het 'n dringende versoek tot die teologie gerig om 'n bydrae te lewer ten opsigte van die verklaring en verstaan van die historiese werklikheid. Binne die intellektuele uitdaging van interpretasie en singewing van die tragiese gang van die geskiedenis het die motief van die gerig van God weer nuwe aktualiteit verkry. Teologies was dit 'n noodwendigheid om God met hierdie 'negatiewe' gang van die geskiedenis in verband te bring. Om hierdie rede het die uitspraak van $\mathrm{Hegel}^{4}$ ([1821] 1970:503), naamlik dat die wêreldgeskiedenis die wêreldgerig is, sy aktualiteit behou. As gevolg van 'n misverstand van Hegel se bedoeling, het sekere teoloë (kyk Amelung 1984:493) hulle eie tyd as die voorspel tot die einde verklaar. Hulle het hulle politieke situasie as God se gerig gesien. Die geskiedenis is binne die raamwerk van die apokaliptiek uitgelê. Die einde het vir hulle aangebreek. God is besig om aan Europa 'n einde te maak. 
Binne hierdie teologiese situasie het Jürgen Moltmann se 'teologie van die hoop' ontstaan. Moltmann (1977:210-217) het Hegel se stelling anders as sy voorgangers uitgelê, deur op die nuwe sintese wat in die dialektiese proses ontstaan, klem te lê. Vir hom was daar dus hoop op ' $n$ beter toekoms. Die eindtyd het nie aangebreek nie en die geskiedenis het nie tot 'n einde gekom nie. Volgens hom het daar 'n nuwe tydperk van geregtigheid, menswaardigheid en vrede aangebreek.

Vyf en twintig jaar na sy 'teologie van die hoop' hou Moltmann nog steeds by sy aanvanklike teologiese program. In sy hantering van die leerstuk van die eindoordeel (Moltmann 1989:359-363) maak hy van die tema van die geregtigheid die relevante en ter saaklike toegangswyse tot hierdie leerstuk. Volgens hom is die verlange na uiteindelike geregtigheid, as reg wat geskep word, die hart en kern van die hoop op 'n eindoordeel ${ }^{5}$. Hierdie vertroue op uiteindelike geregtigheid gaan, volgens Moltmann, terug na die hoop van die slagoffers van die wêreldgeskiedenis. Die motief van die eịndoordeel is volgens hom eers later in 'n strafgerig oor die boosdoeners omskep. Dit impliseer dat God as die Wêreldregter oorspronklik 'n God was wat aan oṇreglydendes reg verskaf, en eeps later in die Strafregter van die mensheid vir wie daar gesidder word, verander is.

Ten spyte daarvan dat voorstellings van 'n gerig na die dood alreeds in die Egiptiese en Iranese godsdienste voorgekom het, is Moltmann (1989:359) tog van mening dat die Ou Testamentiese gerigsvoorstelling vanuit Israel se verbondservarings ontwikkel het. Volgens hom kom die Ou Testamentiese gerigsvoorstelling op die volgende neer: Jahwe gaan op die 'dag van die Here' oor al die volke gerig hou. Hierdie dag lê nie aan die anderkant van die dood nie, maar gaan in die 'laaste dae' plaasvind (Ješ 2: 2; Miga 4:1). Die gevolg van hierdie 'regsproses' sal 'n vredesryk wees waarin die vol ke van hulle swaarde ploegskare en hulle spiese sekels sal maak (Jes 2, 9, 11; Miga 4).

God, die Vredesregter, se geregtigheid skep dus vrede (Ps 94, 96-99). Hierdie vrede sal, volgens Moltmann (1989:360), geskep word in 'n proses waarin Jahwe aan die onmagtige en onderdrukte Israel reg verskaf en aan die onderdrukkers onreg. Hierdie hoop het 'n element van die Messiasverwagting van Israel geword. Die Messiaskoning sal sy koninkryk vestig en dit met reg en geregtigheid instand hou om op hierdie wyse vrede en voorspoed vir ewig te verseker (Jes 9:6). Hy sal die armes billik verhoor en die ootmoediges regverdig oordeel (Jes 11:4). Hierdie geregtigheid en vrede sal tot binne in die diereryk strek (Jes 11:6). Vir Moltmann is die geregtigheid van God daarom geen lonende en straffende geregtigheid nie, maar 'n regskeppende en verlossende geregtigheid (Jes 1:27). Die 'dag van die Messias' is daarom soos die 'dag van Jahwe' vir hom geen dies irae nie, maar 'n dag waarop die vrede begin. Deur sy oordeel oor onreg en vyandskap skep die Messias die omstandighede vir 'n universele ryk van vrede. 
Met hierdie sistematisering doen Moltmann (1989:360-361) afstand van die apokaliptiese vergeldingstrafreg. Die Joodse apokaliptiek het die voorstelling van die wêreldgerig met die koms van die Seun van die mens verbind. Hierdie dag staan ook binne hierdie denke as die 'jongste dag' bekend, omdat hier nie net 'n geskiedenisepog nie, maar die hele wêreldgeskiedenis tot 'n einde kom (4 Esra 5:73). Tydens hierdie gerigsproses gaan die Seun van die mens elke individu volgens sy werke oordeel. Die konflik tussen die vromes en die goddeloses sal ook deur die 'swaard van God' tot finale beslissing gebring word. Vir die een sal daar 'n ewige lewe wees en vir die ander 'n ewige verdoemenis. Hierdie vasstellende en reagerende geregtigheid van die apokaliptiek het die regskeppende geregtigheid van die verbondsteologie duidelik verdring. Die wêreldgerig is omskep in 'n strafgerig volgens die maatstaf van vergelding van die goeie met goeie en die bose met bose. Die nuwe tydperk van geregtigheid is daarom ook net vir diegene bedoel wat hier en nou as die goeies geld.

Moltmann meen dat daar in die Nuwe Testament 'n dilemma in hierdie verband te vinde is. Soms word daar by die verbondsteologie en soms by die apokaliptiek aansluiting gevind. In 'n gedeelte soos Matteus 25:31-46 kom selfs beide motiewe voor. Moltmann los hierdie dilemma op deur 'n teorie met behulp van die eliminasie van weersprekende tekste op te bou. Hierdie teorie kom op die volgende neer: Jesus het aan die regloses die reg van die Goddelike erbarming en aan die ongeregtes die die reg van die Goddelike vergewing kom aanbied. Paulus verstaan die geregtigheid van God daarom as ' $n$ regskeppende en regverdigende geregtigheid en nie as 'n vergeldingstrafreg nie. Die liefdesbegrip van die Nuwe Testament skakel die motief van vergelding nog verder uit. Liefde, volgens Jesus, is ten diepste liefde vir die vyand. Hierdie liefde is ten diepste aan die kruis geopenbaar. Deur hierdie liefde skep Jesus vir Hom sy ryk van vrede. Volgens Moltmann is dit dus ondenkbaar dat die komende Christus volgens ander maatstawwe gaan oordeel as wat die aardse Jesus verkondig en uitgelewe het. Daar kan volgens hom nio 'n botsing tussen liefde en hoop wees nie. Die totale Christelike boodskap moet 'n konsistente boodskap wees. Om hierdie rede elimineer Moltmann die apokaliptiese motiewe van die Nuwe Testament om tot die volgende uitleg van die eindoordeel te kom:

Auf der anderen Seite steht die christliche Eschatologie, die Jesus in der Gestalt des Weltenrichters sieht und erwartet, daß er endgültig die Rechtlosen ins Recht setzt und die Ungerechten gerecht macht, daß er die Feindschaft, aber nicht die Feinde, für immer $>>$ totet $<<$ sondern diese durch die Kraft seiner Liebe verwandelt, um endlich sein Reich des Friedens ohne Ende aufzurichten. Das Ziel des Gerichtes Jesu ist nicht 
die allseitige Vergeltung, sondern die Gründung des Friedensreiches auf derjenigen Gerechtigkeit, die alle Feindschaft überwindet. Der Richter richtet dann sozusagen nach Art eines Resozialisierungsstrafrechtes.

(Moltmann 1989:363)

Vir Moltmann is die eindoordeel dus nie die begin van die einde nie, maar eerder die aanvang van die nuwe skepping. Christus kom nie om af te breek nie, maar om op te bou. Dit is vir hom die Messiaanse uitleg van die eindoordeel.

'n Mens kan sê dat Moltmann Luther se standpunt tot die uiterste konsekwensies deurgetrek het, en wel in dié opsig dat die eindoordeel vir hom hoegenaamd geen vrees inhou nie, aangesien God se straf nie meer 'n straf is wat vrees inboesem soos Mozart dit nog geken het nie. 'n Mens sou beslis nie verantwoordelike prediking bevorder deur Moltmann se uitleg van die eindoordeel as handleiding aan te beveel nie. Daarvoor kan minstens die volgende redes aangevoer word:

* Die probleem met Moltmann se teologie is dat hy die wềreldgeskiedenis byna as heilsgeskiedenis verstaan. Die sekulêre geskiedenis loop by hom te reglynig in die koninkryk oor. Die daarmee samehangende probleem is dat God nie werklik volgens Moltmann in die geskiedenis handel nie, aangesien God deur sy voorsiening dit eintlik net vir die mens moontlik maak om die wêreldgeskiedenis in die rigting van 'n ewige vredesryk te laat ontwikkel.

Vanuit die Skrif is dit duidelik dat die geskiedenis nie net 'n progressiewe menslike regsproses is nie. God handel en gryp in. Hy straf en Hy beloon. Hy is daartoe genoodsaak as gevolg van die mens se sonde. Om hierdie standpunt te begrond, wil ek graag op die volgende wys: dit is baie duidelik dat God se oordeel nie net regskeppend van aard is nie. Sy gerig is baie beslis straffend, pynigend en verwerpend van aard. Afgesien van ander literatuursoorte, maar veral die profetiese literatuur - waarin dit baie duidelik is dat God se gerig nie net regskeppend is nie - bewys die wysheidsliteratuur hierdie teorie van Moltmann cok as ongeldig. Binne die hele debat oor die sogenaamde 'doen-gevolg-samehang' in die wysheidsliteratuur, is daar tot onlangs beweer dat die samehang van verkeerd-doen en straf en goed-doen en beloning die openbaring van die lewensorde is wat deur God gewaarborg word. Daar is gese dat ons in die lewe met 'n 'schicksalwirkende Tatsphäre' te make het - 'n sfeer waarin die bose daad op die dader terugslaan en die goeie daad die dader ten gunste sal kom. Hierdie is 'n natuurlike proses waarin God self nie inmeng nie. Bestraffing en beloning sal plaasvind, aangesien God se 
wêreld op geregtigheid - die geregtigheid van regverdige straf en beloning gefundeer is (kyk Koch 1955; Von Rad 1970; Schmid 1968). Binne hierdie konteks is dit van belang dat Horst Dietrich Preuß (1991:209-220) in sy 'Teologie van die OT' aangedui het dat hierdie 'doen-gevolg-samehang' wél met God se ingrype en handeling te make het. Na sy uitgebreide ondersoek oor beloning en straf op grond van mense se doen en late, kon hy sê dat God die wêreld nie deur 'ordeninge' regeet of die geskiedenis deur menslike wensbeelde laat ontplooi nie. God self bepaal die gang van die lewe deur ingrype in en reaksie op mense se doen en late. Sy geregtigheid kan nie in 'ordeninge' vasgevang word nie, aangesien Hy die lewende God is wat handel en so wendings teweegbring. Agter die 'noodlotwerkende sfeer van die daad' staan God en nie 'n blinde natuurproses nie (PreuB 1991:218 \& 220). Hierdie verwysing (daar is ongelukkig nie méér ruimte as vir net hierdie verwysing nie) behoort voldoende te wees om aan te dui dat God se gerig inderdaad reagerend van aard is. Daar is dus nie ' $n$ kans om op grond van eerlike eksegese ' $n$ ideologie van vrede, regstellende geregtigheid en absolute verdraagsaamheid teenoor die onreg te verdedig nie. Wat egter duidelik uit die Skrif afgelees kan word, is dat God ook vrede en geregtigheid skep deur ongehoorsaamheid en onreg tot 'n einde te bring en die sondaars te straf. Dit is juis gerusstellend om te weet dat God, in teenstelling met so baie eietydse owerhede, nog onreg en geweld tot ' $n$ einde kan bring en die boosdoeners gaan straf.

* Ek is oortuig daarvan dat Moltmann se voorstel vir die verstaan van die eindoordeel meer deur huidige tendense rondom die strafreg en doodstraf bepaal is as deur eksegetiese oorwegings. Moltmann het duidelik 'n poging aangewend om 'n gerigsvoorstelling met die gees van die tyd te versoen. Binne die Westerse samelewing het daar veral in die laaste dekades 'n dramatiese wending rondom straf en veral doodstraf ingetree (kyk veral Douma 1990:60-93; Gründel 1981:126-140). Die doodstraf word as onbeskaafd en barbaars uitgemaak. Dit is nie versoenbaar met die liefdes- en geregtigheidbegrippe van die moderne tyd nie. Moltmann sal sê dat enige voorstelling van God wat Hom ná aan 'n uitbeelding van 'n genadelose laksman bring, vir die moderne bewussyn onaanvaarbaar sal wees. 'n Mens sal seker moet toegee dat die wêreldbewussyn, die begrip van die strafreg en die emosies rondom die doodstraf op die Godsbegrip kan inwerk, maar sekerlik mag dit tog nie deurslaggewende invloed hê nie. Die Skrif se voorstelling van God mag tog sekerlik nie deur die tydsgees oorwoeker word nie. 
Wanneer daar weer in die geloof aanvaar word dat die gang van die lewe nie net deur menslike ywer en godsdienstige kousaalsamehange nie, maar ook deur God se historiese dade bepaal word, sal die eksegetiese oog vir God se toornige dade in die geskiedenis geopen word. Feitlik die hele Ou Testament getuig van God se toornige reaksies op die mens se sonde. Die oergeskiedenis is niks anders as 'n verhaal van die mens tussen gerig en heil nie (Zimmerli 1975:147-154). Die verhale van die verlore paradys, Kain en sy vervloeking, die sondvloed en die toring van Babel is almal bewyse van die waarheid van hierdie stelling. Alhoewel God nie 'n bose laksman is, wat mense vir ewig wil straf en pynig nie, is Hy hulle daarom altyd weer genadig en laat Hy die sonde nie ongestraf nie. Die verhalende gedeeltes van die Ou Testament laat ons egter weer eens tot die indruk kom dat God se straf verskriklik kan wees. Die homoseksuele kolonies, Sodom en Gomorra word totaal verwoes (Gen 19:5), die farao se se leër word totaal uitgewis (Eks 14), Moses word verhinder om die beloofde land in te gaan (Num 20), Mirjam,word melaats gelaat omdat sy met Moses getwis het oor sy Kussitiese vrou (Num 12), en Salomo word op grond van sy afgodery van dele van sy ryk ontneem (1 Kon 11).

Hierdie Godsbegrip van die God van Israel wat die sonde, ongeregtigheid en afgodery straf - en selfs vernietigend straf - maar nogtans altyd weer genade betoon, word ook vanuit die profetiese literatuur herkenbaar (Westermann 1978:109-119; Zimmerli 1975:161-211; Kaiser 1993:126-138). Feitlik elke profeet het die God van Israel as die liefdevolle Verbondsgod, wat selfs sy eie volk straf, laat wegvoer en verstoot, voorgestel. Op geen manier is dit eksegeties en Bybels-teologies moontlik om die Godsbeeld van die profete anders voor te stel as sou God nie ook toornig wees nie. Die apokaliptiese literatuur met sy voorstellings van die komende Regter wat skeiding tussen mense en volke gaan bring, mag ook nie vanuit die Bybel weggewens of weggeargumenteer word nie. Hierdie uitsprake vorm belangrike skakels in die beeld van God as Regter, Heerser en Erbarmer. Dat God finaal deur middel van sy gerig oor die goddelose magte gaan triomfeer (Joël 3; Sag 13; Eseg 38), oor alles en almal Heer sal wees en sy gerig op hierdie wyse tot ' $n$ einde sal bring, is inderdaad belangrike elemente van die Bybelse boodskap. Uiteindelike geregtigheid is ook nie werklik voorstelbaar sonder 'n finale universele gerig soos wat dit in die apokaliptiese literatuur (EtHen 91:15; I 4 Esr 7:70; Dan 7:26) voorgestel word nie. 'n Gerig wat nie almal ook alle vorige geslagte - insluit nie, sal nie die diepste verlangens na geregtigheid kan bevredig nie.

Om hierdie rede stem ek met Kuitert (1992:174-175) saam as hy in sy uitleg van die belydenis aangaande die eindoordeel die volgende stel: die feit dat daar ' $n$ finale oordeel aan die einde van die dae gaan wees, hou vir ons aan die een kant dié troos in dat die wêreldgeskiedenis nie die wêreldgerig is nie. Die lot wat ons tref, is nie die laaste oordieel nie. Op hierdie wyse word ons lewensgang van diepgaande onreg ge- 
spaar. Aan die ander kant bevredig die eindoordeel weer ons regverdigheidsgevoel. Alle mense het hierdie gevoel dat onreg nie ongestraf gelaat kan word nie, dat die moordenaar nie oor sy offer mag triomfeer nie. Die eindoordeel bevredig ons drang na retribusie, aangesien daar deur Christus, uiteindelik regverdig oor alle mense geoordeel gaan word.

Ek stem verder ook met Kuitert saam dat die eindoordeel as etiese motief behoue moet bly. Die mening van die moderne Calviniste, soos Moltmann en Walter Kreck (1961), dat die eindoordeel nie as etiese motief gebruik mag word nie, vind ek onaanvaarbaar. Wanneer die werklikheid van die eindoordeel verswyg word, word die weg juis vir moord en doodslag geopen, sonder die vrees vir uiteindelike verantwoording. Volgens Prediker 11:9 en 12:14 is die eindoordeel juis dié motief. wat tot eties verantwoordbare optrede aanleiding sal gee. Die ervaring het geleer (minstens in ons jongste geskiedenis) dat die ideaal van die skep van 'n volmaakte samelewing meer inhumaniteit as humaniteit oplewer, en daarom het dit tyd geword om die eindoordeel weer doelbewus in die etiek aan die orde te stel.

Die gerigsmotief mag eties bruikbaar gemaak word op voorwaarde dat etiek nie, soos by die Jode, in 'n heilsleer omslaan nie. In die apokaliptiek word die gerigsmotief op die verwagting van 'n wêreldgerig, wat aan die einde van die geskiedenis gaan plaasvind, toegespits. By hierdie geleentheid gaan al die volke en elke individu voor die regterstoel van God verskyn om daar 'n regverdige vergelding vir hulle goeie en slegte dade te ontvang. Daar sal 'n algemene opstanding uit die dood wees. Die een sal opstaan tot die ewige lewe en die ander een tot die ewige verdoemenis. Die aardse geskiedenis sal hier tot 'n einde kom en daarna sal die nuwe wêreld van God aanbreek waarin daar geregtigheid, vreugde en saligheid sal heers (Dan 12:2). God se oordeel sal regverdig en onveranderlik wees. Om hierdie rede is dit vir elke mens noodsaaklik om só te lewe dat hy by die eindoordeel vrygespreek sal word. Hy moet die wet van God daarom nougeset gehoorsaam, aangesien die wetsgehoorsaamheid God se maatstaf by die eindoordeel oor die werke sal wees.

In die sinagoge is die gerigsmotief paraneties aangewend om die vromes te vermaan tot wetsgehoorsaamheid en die versameling van 'n groot genoeg skat van goeie werke sodat hulle by die eindoordeel nie in die benoudheid sal kom nie. Dit is volgens die sinagoge van belang dat die vrome 'n oorwig van verdienstelikhede teenoor oortredinge sal hê, aangesien dit teenoor mekaar opgeweeg sal word en daar volgens die val van die skaal uitspraak gelewer sal word.

Hierdie paranetiese aanwending van die gerigsmotief het selfs tot 'n belangrike aspek van die Joods-Hellenistiese sendingprediking ontwikkel (kyk Lohse 1988:80). Gedagtig aan die feit dat die motief oor die eindoordeel oor die werke vir die meeste godsdienste van die ou nabye Ooste bekend was, het die Jode daarop gekonsentreer om 
hierdie mense tot boete en omkeer in die lig van die eindoordeel te vermaan. Die materiële inhoud van die bekering moes natuurlik vanuit die Joodse wet geput word. Op hierdie wyse was die gerigsmotief ' $n$ instrument tot die ekspansionisme van die Joodse wet en moraal. Anders gestel: die bewussyn dat almal eendag voor die regterstoel van God (die God van Abraham, Isak en Jakob) moet verskyn, het aan die sedelike verantwoordelikheid, soos deur die wet gestalte gegee, verpligtende karakter gegee.

Die probleem met die Joodse aanwending van die gerigsmotief in die etiek, en die toespitsing van die etiek op die eindoordeel, is dat die etiek die poort tot die saligheid word - of anders gestel: dat etiek heilskarakter kry. Menslik gesproke moet hierdie weg tot saligheid in groot onsekerheid en twyfel eindig. Troostelose aanvegting móét die uiteinde van hierdie weg wees. Die Pauliniese regverdigingsleer bied ongetwyfeld 'n beter alternatief. Nogtans sal 'n mens ook met die argument rekening moet hou dat die wet ' $n$ heilsweg bly, wat aan mense wat nie die voorreg gehad het om die evangelie te hoor nie, die geleentheid bied om tog wel gered te word. Wolfhart Pannenberg (1993:654-672) is een van die verdedigers van hierdie standpunt.

Pannenberg (1993:656-667) het, net soos Calvyn, geoordeel dat die vraag na die maatstaf, en nie die vraag na die persoon van die Regter nie, die belangrikste vraag binne die debat oor die eindoordeel is. Hy wys daarop dat daar in die Bybel ' $n$ aantal weersprekende uitsprake oor die persoon van die Regter voorkom. Daar is talle tekste in die Bybel wat nie in die Christus die finale Regter sien nie, maar wat God (Matt 6:4, 15, 18; 1 Petr 4:5; Openb 20:11; Rom 2:3-9, 3:6, 14:10; 1 Kor 5:13) of die heiliges (1 Kor 6:2-3; Matt 19:28) as die finale gerigsinstansie sien. Hy gee toe dat Christus 'n funksie by die eindoordeel sal vervul, maar meen dat dit nie so maklik is om uit te maak wat hierdie funksie sal wees nie. Daar word in 1 Tessalonisense 1:10 gesê dat Christus ons van die komende oordeel sal red. 1 Petrus 1:13 praat ook van die genade wat ons by die wederkoms van Christus sal ontvang. Die Wederkomende blyk dus eerder 'n Voorspraak by die oordeel van die Vader, as self die Regter te wees. Dit stem ook met die versekering van die Johannesevangelie ooreen dat Jesus nie gekom het om te oordeel nie, maar om te red (Joh 3:17; 12:47). Vir Johannes geld dit ook nie net ten opsigte van die aardse Jesus nie. Alhoewel daar gestel word dat die Vader die oordeelsfunksie aan die Seun oorgedra het (Joh 5:22-29), word daar ook van die komende eindoordeel gesê dat Jesus niemand persoonlik gaan veroordeel nie, aangesien Hy weer kom om te red. Wat wel duidelik is, is dat die toekoms en bestemming van 'n mens deur die persoon en woorde van Jesus bepaal word. Johannes 12:48 sê: 
Wie my verwerp en nie my woorde aanneem nie, het reeds iets wat hom veroordeel: die woorde wat Ek gespreek het, sal hom op die laaste dag veroordeel.

Volgens Pannenberg (1993:661) kom Johannes se standpunt van die woord van Jesus as maatstaf van die eindoordeel ooreen met Jesus se uitsprake in onderskeidelik Markus 8:38 en Lukas 12:8-9:

Wie hom dan vir My en my woorde skaam te midde van hierdie ontroue en sondige geslag, vir hom sal die Seun van die mens Hom ook skaam wanneer Hy kom saam met die heilige engele, en beklee is met dieselfde heerlikheid as sy Vader.

(Mark 8:38)

Elkeen wat hom voor die mense openlik vir My uitspreek, vir hom sal die Seun van die mens Hom ook openlik uitspreek voor die engele van God. Maar hy wat My voor die mense verloën, sal voor die engele van God verloën word.

(Lukas 12:8-9)

Eintlik is dit nie net die glo van die Woord nie, maar ook en veral die gehoorsaamheid aan en die doen van die Woord wat die maatstaf by die eindoordeel sal wees. Hiervan is Matteus 7:22-23; 25:31-46 en Lukas 13:25-27 sprekende bewyse. Op grond van hierdie argumentasie kom Pannenberg dan tot die volgende konklusies:

Der entscheidende Inhalt der .... Wiederkunft Christi zum Gericht dürfte also sein, daß die Botschaft Jesu den Maßtab für das Gericht darstellen wird. Wer das Gericht vollzieht und das Urteil sprechen wird, ist eine demgegenüber untergeordnete Frage. Damit verschwindet auch der Anschein eines unfairen Partikularismus in der Vorstellung, daß das Heil für alle Menschen abhänge von ihrer Gemeinschaft mit Jesus Christus .... Viele Menschen sind nie von der Verkündigung des Evangeliums erreicht worden. Ausschlaggebend für ihr ewiges.Heil kann nicht die von historischen und lebensgeschichtlichen Zufälligkeiten abhängende Tatsache persönlicher Begegnung mit Jesus durch die Verkündigung der Kirche sein, wohl aber die faktische Übereinstimmung des individuellen 
Verhaltens mit dem von Jésus verkündeten Gotteswillen. Die Botschaft Jesu bildet die Norm für das Urteil Gottes auch über die Menschen, die Jesus nie persönlich begegnet sind. Das bedeutet ... daß Menschen, die Jesus nicht gekannt, aber die Werke der Liebe getan haben, welche seiner Botschaft entsprechen, faktisch am Heil des Gottesreiches teilhaben und im Gericht Gottes freigesprochen werden, während die nur nominellen Christen von diesem Heil ausgeschlossen bleiben.

(Pannenberg 1993:661)

Pannenberg se standpunt staan dus in skrille kontras met dié van Calvyn. Waar Calvyn op grond van die maatstaf van die geloof alleen geen twyfel oor die gerig van God oor die ongelowige het nie, daar het Pannenberg op grond van die maatstaf van die etiese eise van Jesus geen twyfel oor God se genade vir die liefdevolle ongelowige en sy gerig oor die liefdelose gelowige nie. Alhoewel geloof vir Pannenberg natuurlik 'n wenslike is, meen hy tog dat die werke ook uiteindelik 'n weg tot saligheid kan wees. Hy neem hierdie standpunt in omdat hy God nie as 'n onregverdige Regter wil voorstel nie. Hy wil die God van die Bybel verdedig as 'n God wat aan almal die geleentheid gee om gered te word. Hierdie standpunt van Pannenberg is nie uit die lug gegryp nie. Daar is ' $n$ stewige Bybelse basis vir so ' $n$ standpunt. Dit is veral die evangelie van Matteus wat hierdie posisie verkondig. Dit is daarom nodig dat ons eers indringend na die Matteusevangelie sal kyk.

Volgens Matteus het Jesus as sedeleraar 'n nuwe en groter geregtigheid van sy volgelinge geëis (Schnackenburg 1993:134-151). Die kern van hierdie geregtigheid is die liefde terwyl die barmhartigheid (kyk o a Matt 5:7; 6:36) weer die diepste uitdrukking van die liefde is. Diegene wat nie bereid is om met barmhartigheid teenoor ander op te tree nie, kan nie van God barmhartigheid verwag nie (Matt 18:23-35) - trouens diegene wat nie barmhartigheid tydens hulle lewe betoon nie, sal by die eindoordeel, wat 'n oordeel oor die barmhartigheidswerke sal wees, ontdek dat hulle van die komende Seun van die mens geen genade sal ontvang nie (Matt 25:31-46). Jesus het sy vermaning oor die gebrek aan goeie werke veral tot die gemeente as sodanig gerig (Matt 16:27). Veral die gelowiges, die navolgers van Jesus, moet ingelig wees oor die eindcordeel en sy kriterium. Die res van die mensdom is egter nie van die eindoordeel uitgesluit nie. Die universele horison wat alreeds in die wysheidlike begronding van die bergrede na vore gekom het (Matt 5:45), word hier in die toneel van die eindoordeel herhaal. Die eindoordeel oor die werke het dus 'n universele karakter. Niemand sal dit vryspring nie en almal sal ook by hierdie gebeure kan baatvind. Almal (veral die gemeente) word daarom opgeroep tot die doen van barmhartigheid, aangesien dit die maatstaf vir redding en verdoeming gaan wees. 
Die vraag is of hierdie konsep van die eindoordeel oor die werke nie met die res van die evangelie in stryd is nie? Sou 'n mens nie verwag dat die genade moet triomfeer nie? Sou 'n mens nie verwag dat die Seun van die mens met diegene wat nie aan die hoë eise van die barmhartigheid kan voldoen nie, barmhartig sal omgaan nie? Wanneer Jesus aan die tollenaars en prostitute sê dat hulle voor die skrifgeleerdes in die koninkryk sal ingaan, omdat hulle hul op grond van Johannes se prediking bekeer het (Matt 21:31), sou 'n mens dan nie so iets soos 'n algemene amnestie vir gelowiges kon verwag nie? Verder: het Jesus dan nie 'tot vergewing van sondes' (26:28) gesterf vir almal wat aan sy verbond wil deelhê nie? Volgens Schnackenburg (1993:147-149) moet hierdie spanning tussen barmhartige vergewing en verdoemingsoordeel, wat by Matteus so duidelik na vore kom $(7: 23 ; 8: 12 ; 13: 41-50 ; 18: 34 ; 22: 13 ; 24: 51 ; 25: 30$, $41,46)$, vanuit die vooronderstellings van sy etiek verklaar word. Hierdie veronderstellings kom neer op die noodwendige doen van die liefde as antwoord op die genade van God, en die noodwendige opwelling van die woede van God oor die minagting van sy liefde op grond van die nalaat van die doen van die liefde. Genade en gerig is dus volgens Schnackenburg nie 'n teenspraak nie, aangesien hulle die voorkant en rugkant van Jesus se etiek is. In teenstelling met Pannenberg moet dit dus hier gestel word dat Matteus die etiek nie as heilsweg nie, maar as antwoord op die genade gesien het.

Jesus het streng morele verwagtings van sy volgelinge, die begenadigdes, gekoester. Wie nie aan hierdie verwagtinge (die toon van die dankbaarheid) voldoen nie, sal by die eindoordeel nie op genade kan reken nie. Die gemeentelid wat hom by die wetsoortreders skaar (Matt 7:23; 13:41) en dié een wie se dade nie met die eise van die Here in ooreenstemming is nie (Matt 22:11-13), sal uit die komende Ryk uitgesluit word. Om hierdie rede het Matteus (Matt 5:16; 7:16, 20; 21:43) by sy gemeente dringend om sedelike prestasies aangedring. Hy was daarvan bewus. dat gemeentelede wat ten opsigte van die eis tot meerdere geregtigheid gefaal het, by die eindmaal uitgesluit sal word (Matt 22:1-14).

Alhoewel Matteus die grenslose liefde van die Vader teenoor afgedwaaldes ken (Matt 9:12-13), bly hy egter die klem plaas op die bekering van die afgedwaalde as voorwaarde vir die opname in die koninkryk (Matt 21:28-32). Ten opsigte van die bekering van die afgedwaaldes het die gemeente 'n groot verantwoordelikheid. Dit is haar verantwoordelikheid om die afgedwaaldes op te soek en tot omkeer te help (Matt 18:12-14), aangesien hulle andersins verlore sal gaan (Matt 18:17). Die opmerklike is dat Matteus die onus eintlik op die gemeente plaas. Dit word by die gemeentelede ingeskerp dat hulle vir die medemens sorg moet dra (Matt 24:44-50), aangesien die gelowiges na die eindoordeel oor die werke op pad is waar nie na die alvergewende goedheid van God nie, maar na die verpligte barmhartigheidswerke van die mens gevra sal word. Die gelowige wat vanuit die skenkende goedheid van God lewe moet weet dat hy 'n sedelike verpligting teenoor sy medemens het. Kom hy dít nie na nie, moet hy weet dat hy onder die dreigende verlies van die genade leef (Matt 18:21-35). 
Matteus dreig nie net met die gerig nie, maar lok ook met die loonmotief. Hulle wat in goeddoen volhard het sal soos die son in die koninkryk skitter (Matt 13:43), sal saam met die aartsvaders aan die tafel sit (Matt 8:11), sal vir hulle werke ryklik beloon word (Matt 25:21, 23) en sal in die ewige lewe opgeneem word (Matt 25:46). Met hierdie kombinasie van straf en loon wil Matteus die gemeentelede tot goeie werke aanspoor, sodat hulle nie by die eindoordeel verwerp sal word nie.

Die vraag is nou of Matteus nie dalk 'n Fremdkörper in die Bybel is nie? Kom die gedagte van die eindoordeel oor die werke ook by Paulus voor?

Paulus het in ' $n$ groot mate in sy sendingprediking by die sendingperspektiewe van die sinagoge aangesluit. Ook hy het, soos die sinagoge, verwag dat die heidene hulle van die afgode tot die ware God sal bekeer (1 Tess 1:9) — ja, hierdie God wat rekenskap oor doen en late gaan eis (2 Kor 5:10). Paulus bly dus binne die denkraamwerk van nie alleen die Ou Testament (Ps 62:13; Spr 24:12; Job 34:11) nie, maar ook dié van die vroeë Jodendom (Jub 5:15; EthHen 100:7) en die oerchristendom (2 Kor 5:10) wat die gedagte verkondig het dat God elke enkeling volgens sy werke sal beoordeel. 'Werke' is die dade wat 'n persoon as 'n regverdige of as 'n goddelose bewys. Die 'werke van die wet' beteken by Paulus (Gal 2:16; Rom 3:20, 28), sowel as in die Joodse tradisie (4Qflor 1:7; SyrBar 57:2), die afsonderlike gebodsvervullings, terwyl die 'werk' van 'n Christen (1 Kor 3:13) sy totale menswees onthul. Dat hierdie goeie werk eendag deur God beloon en die bose werk deur God verwerp gaan word is vir die apostel 'n sekerheid (1 Kor 3:14; 9:17). Die apostel verkondig daarom dat almal wat die wil van God doen, van God loon (1 Kor 3:8, 14; 9:17), lof (1 Kor 4:5) en roem (1 Kor 9:15; Fil 2:16) sal ontvang. Daarom roep hy sy gemeentes tot die doen van die goeie op (Gal 5:16-26; 1 Kor 6:7-11; Fil 2:12-16; Rom 12:2).

Die indruk kan maklik ontstaan dat Matteus en Paulus 'n eenvoudige loonteologie leer, wat dit ook vir ongelowiges moontlik makk om op grond van goeie werke die ewige lewe as loon te ontvang. Dit is egter alles behalwe die volle verhaal van die Skrif.

Heinrich Graffmann (1936:127) wys tereg daarop dat die feit dat God beloon nie met die geregtigheid van God begrond kan word nie, aangesien sy geregtigheid Hom nie tot loon verplig nie. Sy loon kan ook nie vanuit die prestasies van die mens begrond word nie, aangesien die mens ook sonder die hoop op loon tot diens aan Hom verplig is. Dat die mens loon vir sy werke ontvang, is eerder 'n bewys van God se goedheid en genade, aangesien Hy die ware geheimenisse van die harte ken. Afgesien van die feit dat God se loon genadeloon is, is sy beloning van werke niks anders as die beloning van werke wat in Homself hulle oorsprong het nie. Werke wat nie uit God self kom nie is tevergeefs (Matt 7:22). Werke van hulle wie se harte van God verwyder is, sal ook geen loon van God ontvang nie (Matt 15:8-9). Om hierdie rede stel Matteus dit so radikaal, dat alle plante wat nie deur die Vader geplant is nie, uitgeroei 
sal word (Matt 15:13). Net arbeid wat in die wingerd van die Here gedoen word (Matt 20:1-16), navolging van Jesus (Matt 10:38), die verlies van lewe ter wille van Hom (Matt 10:39) en verlies aan aardse middele en voordele ter wille van Hom (Matt 19:29) sal beloon word.

Ook by Paulus gaan die argument in dieselfde rigting wanneer hy sê dat alles wat nie uit die geloof gedoen word nie, sonde is (Rom 14:23). Dit beteken dat die werke van die ongelowiges nie outomaties tot redding kan lei nie. Werke as sodanig gaan nie deur God tot geregtigheid gereken word nie, aangesien die werke wat voor God geld werke moet wees wat tot bewys van geloof dien (Jak 2:14-26). Die werke van gelowiges (en net van gelowiges) wat beloon word, is daarom die werke wat as bewys dien van hulle aanvaarding van die genade in Jesus Christus.

Fritz Heidler (1983:150) wys daarop dat daar ook vanuit 'n ander perspektief 'n eenheidsband tussen werke en geloof bestaan, wat die argument van redding op grond van werke alléén nog meer diskrediteer. Op die vraag aan Jesus wat gedoen moet word sodat die werke van God gedoen sal word, antwoord Jesus: daar moet geglo word (Joh 6:28-29). Geloof is dus die belangrikste werk. Die werk van God in Christus is dus die goeie werk wat hier ter sprake kom.

Paulus kom ook met 'n ander omweg by bogenoemde waarheid uit. Naas sy kennis van die eindoordeel as onthulling van al die werke van die mens, ken Paulus egter ook die Ou-Testamentiese voorstelling van God as dié een wat die verborge dinge van die hart ken (Rom 2:16; 1 Kor 4:5; Jer 17:10; Spr 17:3). Hieruit weet hy dat die mens voor God méér is as enkele werke of die som van die werke wat by die eindoordeel sigbaar sal word (1 Kor 3:15; 5:5; 11:32). Vir die mens wat onder die mag van die sonde vervalle is, beteken dit dat hy nie deur enkele goeie dade en 'werke van die wet' (Gal 2:16; Rom 3:20; $9: 32$ ) by die eindoordeel vrygespreek sal kan word nie. Die vryspraak is alleen moontlik wanneer dit deur God se vrye genade moontlik gemaak word en wanneer Hy vir ons 'n Voorspraak vir hierdie gerigsproses beskikbaar stel. Volgens Paulus is Christus hierdie Voorspraak en genade van God (Rom 8:34). Hy het vir ons die soendood gesterf waardeur ons bevryding van die sonde en 'n nuwe bestaan in geregtigheid ontvang het (2 Kor 5:17, 21).

Paulus ken nie net die verpligting nie, maar ook die vloek wat die wet meebring (Gal 3:10-11). Alhoewel hy weet dat Christus 'n verpligting op hom plaas om die wet te gehoorsaam, en alhoewel hy 'n vreugde vind in die gehoorsaamheid aan die wet, weet hy dat hy as 'n sondaar nie aan hierdie hoë eise kan voldoen nie (Rom 7:21-23). Sonder om sy morele verantwoordelikhede te ontduik, hou Paulus vir sy redding aan die genade van God in Christus Jesus vas. Hiervoor weet hy is geloof nodig. Daarom bekeer hy hom, sodat hy by die wederkoms van Christus vrygespreek kan word. 
Die bekering tot God word aan die belydenis aangaande Jesus Christus gebind. Hierdie belydenis konsentreer nie net op die wederkoms van die opgestane Heer tot die oordeel oor die werke (Rom 2:1-16; 14:10-12; 1 Kor 3:12-15; 4:4-5; 2 Kor 5:10) wat op die 'dag van die Here' (1 Tess 5:2; 1 Kor 5:5; 2 Kor 1:14; Fil 1:6; 10; 2:16) gaan plaasvind nie. Die belydenis van die gelowige moet volgens Paulus ook op die blye verwagting van die Wederkomende konsentreer, aangesien Christus ook tot ons redding kom (1 Tess 1:10). By die wederkoms sal ons beloofde heil bewaarheid word (Fil 3:20-21; Rom 8:23; 13:11) en die heilskeppende geregtigheid van God sal oor alle bose magte finaal triomfeer (1 Kor 15:24-28; Rom 8:38-39). Alhoewel Paulus dus saam met die sinagoge die erns van die eindoordeel beklemtoon en daarop 'n passende sedelike reaksie verwag, verkondig hy teenoor die sinagoge dat Christusgelowiges die eindoordeel met ' $n$ totaal ander verwagting tegemoet $k a n$ tree. Vir hulle is die eindoordeel nie net verskrikking nie, maar ook 'n blye uitsig aangesien Christus hulle voorspraak by die Vader sal wees en hulle op hierdie verskriklike dag sal kom red.

Die sekerheid oor die komende verlossing van die toorn van God by die eindoordeel laat die erns van die eindoordeel vir Paulus nie verdwyn nie. Nog steeds sal daar oor die werke van die mens geoordeel word. Nog steeds word daar dus verwag dat mense, en veral gelowiges, die wet soos saamgevat in die liefdesgebod, nougeset sal uitlewe. Die redding by die eindoordeel verlaag en verminder die sedelike verpligtinge geensins nie. Die regverdigingsleer mag daarom nooit die motief van die oordeel oor die werke ondergrawe nie. Romeine 3:28 mag nie ten koste van Romeine 2:13 beklemtoon word nie. 'n Mens kan nie soos Origenes (kyk Wilckens 1978:143) 'n onderskeiding tussen die mens ante et post fidem maak nie, en dan op grond van Johannes $3:$ 18 beweer dat ' $n$ gelowige nie deur die eindgerig bedreig word nie. Dit is ' $n$ verkeerde uitleg van die regverdigingsleer wat die werke en die oordeel oor die werke vir die gelowige totaal irrelevant laat.

Ek meen dat Ulrich Wilckens in sy oordeel oor hierdie probleem reg het. Wilckens (1978:145-146) sê dat die Pauliniese evangelie geensins werkvyandig is nie. Die geloof verhinder en verhoed die goeie werke geensins nie. Hulle is juis noodsaaklik vir die bevordering van die goeie en die teenwerking van die bose. Die geloof in Christus bevry die mens juis om van sy dade van die verlede weg te breek en nou dade te doen wat met God se wil in ooreenstemming is. Hierdie werke bly ook nog onder die eskatologiese horison van die eindoordeel soos wat Paulus dit in Romeine 2:5-11 skilder. Vir die gelowige gaan dit egter nie meer om heil, al dan nie, maar om die voortgaande verpligting om as gelowige die goeie en die regte te doen. Die verskil met die sinagoge bly egter dat die grote van die skat van die goeie werke nie meer die laaste woord by die eindoordeel sal spreek nie. Dit kom dus daarop neer dat die gelowige verplig is om die wil van God te doen, maar dat hierdie gehoorsaamheid nie meer as verdienste geweeg sal word op ' $n$ wyse dat heil en onheil daarvan afhang nie (Lohse 1988:81). 
Een vraag wat nog gevra kan word, is of die eindoordeel, naas die feit dat dit die begin van die uiteindelike redding is, nie vir die gelowige nog iets meer positief kan inhou nie? Pannenberg gee op hierdie vraag 'n positiewe antwoord. Hy meen dat dit nodig en goed is dat die eindoordeel oor gelowiges voltrek gaan word, aangesien hulle hierdeur van al hulle sondes gereinig gaan word. Hierdie argument grond hy op Paulus se idee van die louteringsvuur (1 Kor 3:10-15). Pannenberg argumenteer as volg: hy deel die mening van die vroeë dialektiese teologie dat die ewigheid die gerig is. Hierdie gerig beteken nie eenvoudig die vernietiging van die eindige skepsel nie, want die ewige God is die Skepper van die wêreld en hou ook as Regter aan sy skeppingswil vas. Die ewigheid is vir die skepsel daarom alleenlik gerig insoverre hy homself teenoor God verselfstandig en geskeie hou. Vir Pannenberg is die gerig daarom nie soseer ' $n$ reaksie op en ' $n$ ingrype in die doen en late van die mens deur God nie. Die gerig beteken volgens hom, eerder dat die mens homself aan die konsekwensies van die sonde uitlewer (Rom 1:24, 28). Die gerig word, volgens Pannenberg (1993:657), op hierdie wyse nie aan die willekeur van God oorgelaat nie, maar Hy voltrek net dit wat in die natuur van die saak lê. Dieselfde gedagte geld vir hom ook ten opsigte van die eindoordeel. Ook hier bestaan die gerig net daarin dat die sondaar aan die gevolge van sy doen en late oorgelaat word6. Pannenberg sien die versoening as 'n verlenging van die skeppingswil van God en die eindoordeel as 'n verlenging van die versoeningswil van God.' Die skeppingsdoel van God impliseer juis dat Hy sy skepsele nie aan die konsekwensies van hulle sonde wil oorlewer nie. Hiervoor het $\mathrm{Hy}$ in die versoeningsdaad van Christus voorsiening gemaak. Die mense wat met God deur Jesus Christus versoen is, word egter nog steeds met die gerig van die ewigheid gekonfronteer. Vir hulle is die gerig egter nie meer tot vernietiging nie, maar tot reiniging van hulle sondes - met ander woorde, tot reiniging van alles wat God se skeppingsbedoeling met hulle weerspreek (Jes 1:25; 66:15-24; Mal 3:2-3). Paulus sê in 1 Kor 3:11-157 vir die evangeliste:

... niemand kan 'n ander fondament lê as wat reeds gelê is nie. Die fondament is Jesus Christus. Of dit goud, silwer, edelstene, hout, gras of strooi is waarmee iemand op die fondament bou, elkeen se werk sal aan die lig kom. Die dag wanneer Christus kom, sal dit duidelik word. Die dag kom met vuur, en die vuur sal die gehalte van elkeen se werk toets. As iemand se bouwerk bly staan, sal hy beloon word; as iemand se werk verbrand, sal hy nie beloon word nie, en tog sal hy self gered word, maar soos iemand wat uit die vuur geruk is. 
Wat Paulus hier vir die evangeliste sê, sê Petrus in 1 Petrus 1:7 vir al die gelowiges. Almal se geloof en werke sal dus deur die vuur van suiwering gaan. Volgens Pannenberg (1993:658) is die reinigingsmotief nie slegs 'n eskatologiese saak nie, maar ook 'n saak van die teenswoordige tyd. Net soos wat die koninkryk deur die geloof reeds teenwoordig is, werk die vuur van die Goddelike gerig reeds deur die boete en die doop. Die doop as die reiniging van sonde is dus ook die antisipasie van die reinigingsoordeel. Die gedoopte kan daarom met die hoop lewe dat hy by die komende oordeel nie geheel en al sal verbrand nie, maar deur die vuur heen gered sal word.

Binne die konteks van sy opvatting oor die louteringsvuur laat hy ruimte vir die Bybelse gedagtes van 'n ewige verdoemenis vir mense wat onversoenlik hulle doelbewus van God afkeer. Hierdie motief mag egter nie Jesus se gedagte van redding vir mense, wat volgens die wil van God gelewe het oorskadu nie. Die vraag bly dus: word mense net op grond van die geloof gered, of kan hulle ook nog op grond van hulle werke gered word?

Saam met Stuhlmacher (1989:45) wil ek stel dat die evangelie net aan die gelowiges redding van God se toorngerig verkondig, maar met die veronderstelling dat as 'n gelowige die evangelie met sy dade aantas of verwerp, daar vir hom geen redding meer sal wees nie (Gal 1:8; 2 Kor 11:13-15; Fil 3:18-19). God en sy Seun laat nie met hulle spot nie (1 Kor 12:3; Gal 6:7-8; Rom 3:5-8). Die eindoordeel is aan Christus toevertrou; en dit beteken dat niemand sonder Christus die saligheid sal ingaan nie. Elke mens behoort daarom in hierdie genadige Heer en Regter te glo en Hom in sy voorskrifte gehoorsaam wees. Vanuit die Johannesevangelie is die geheelperspektief waarskynlik die beste sigbaar:

God het nie sy Seun na die wêreld toe gestuur om die wêreld te veroordeel nie, maar sodat die wêreld deur Hom gered kan word. Wie in Hom glo, word nie veroordeel nie; wie nie glo nie, is reeds veroordeel.

(Joh 3:17-19)

Sonder enige onduidelikheid word hier dus gestel dat 'n mens slegs op grond van sy geloof in Christus gered word. Die een wat glo het nou alreeds volle sekerheid van sy redding. Nogtans word daar onmiddelik in verse 20-21 gesê:

Elkeen wat kwaad doen, haat immers die lig en kom nie na die lig toe nie, sodat sy dade nie aan die kaak gestel moet word nie. Maar wie volgens die waarheid handel, kom na die lig toe, sodat dit duidelik kan blyk dat sy dade in gehoorsaamheid aan God gedoen is. 
Hiermee wil Johannes sê dat dit slegs diegene is wat volgens die wet lewe wat na Jesus toe sal kom, aangesien $\mathrm{Hy}$ as Regter dié Een is wat skeiding tussen wetsgehoorsames en wetsongehoorsames maak. Hierdie dubbele gedagte van Jesus word ook in Johannes 5:24 en 29 herhaal:

Wie luister na wat ek sê, en in Hom glo wat My gestuur het, het die ewige lewe. Hy word nie veroordeel nie maar het reeds uit die dood na die lewe oorgegaan .... Dié wat goed gedoen het, sal opstaan en lewe, en dié wat verkeerd gedoen het, sal opstaan en veroordeel word.

Daar kan dus min meningsverskil daaroor bestaan dat 'n mens op grond van die geloof in Christus gered word, maar dat die gelowige ook nie sonder goeie werke kan wees nie, aangesien hy dan by die eindoordeel verwerp sal word.

Hierdie opmerking bring ons by 'n laaste vraag uit, naamlik of daar werklik so iets soos 'n ewige verdoemenis of hel vir ongelowiges en liefdeloses kan wees? Sal die God van liefde en genade mense werklik tot in alle ewigheid straf?

'n Mens kon drie honderd jaar gelede, en sal miskien oor twee honderd jaar vorentoe, hierdie vraag met groter gemak aan die hand van Bybelse uitsprake beantwoord. Die feit bly eenvoudig dat die sensitiewe morele bewustheid van veral die Westerling, 'n demper plaas op enige poging om God as die strawwende Regter, ja, as die vernietigende Regter voor te stel. Die nuutste poging tot beantwoording van ons vraag getuig daarom ook van die versigtigheid van teoloë om God die Regter nie as wreedaardige laksman voor te stel nie.

Hans Küng (1992:225-237), die omstrede Rooms-Katolieke teoloog, kan nie die moontlikheid van 'n ewige verdoemenis of hel aanvaar nie. Hierdie gedagte is vir hom met die Bybelse Godsbegrip en evangelie in stryd. Die gedagte van 'n hel en die vrees vir die hel gaan onder andere terug na die uitspraak van die Konsilie van Florens in 1442 wat die tese verdedig het dat 'elkeen buite die Rooms Katolieke Kerk ... in die ewige vuur sal kom, wat vir die duiwel en sy engele voorberei is' (Denzinger 1960:nr 714). Küng is van mening dat hierdie uitspraak en voorstellingswêreld onder andere tot die helle-angste en duiwelsgeloof van talle kunstenaars aanleiding gegee het. Die 'val van die verdoemdes' van Luca Signorellis in die dom van Orvieto en die verskillende skilderye van Hieronymus Bosch oor die eindoordeel kan hier as voorbeelde genoem word. Küng kan hom nie met die angswekkende voorstellings van die eindoordeel en hel in hierdie skilderye identifiseer nie. Hy kan ook nie met Mozart se Requiem, wat die eindoordeel as 'n dag van toorn en trane 9 voorstel, identifiseer nie en nog minder met die woorde van die Noorweegse dogmatikus Hallesby (vgl Küng 1992:226) wat in 'n radiopreek gesê het: 
Ich spreche sicher heute abend zu vielen, die wissen, daB sie unbekehrt sind. Du weißt, wenn du tot zu Boden fällst, würdest du direkt in die Hölle stürzen'.

Küng meen dat talle van hierdie mense self angsvallige mense was wat ander in hulle angste wil laat deel. Verder kan hy nie daarmee saamlewe dat die Rooms-Katolieke Kerk, in sy poging om Jode, ketters en hekse van die hel te red, hulle op brandstapels verbrand het nie. Dit is vir hom net so onaanvaarbaar dat pous Paulus VI, op grond van sy verpligting om in lyn te bly met die ortodokse Roomse moraalleer, lidmate en teoloë wat van hom met betrekking tot die gebruik van voorbehoedmiddels ${ }^{9}$ verskil, tot ewige pyn in die hel verdoem. Wanneer godsdienstige leerstukke tot sulke onmenslikhede aanleiding gee, moet hulle volgens Küng verwerp word.

Küng verwerp die gedagte van die hel omdat Jesus nie die hel gepreek het nie. Hy het die evangelie, die blye boodskap verkondig. Hierdie evangelie roep mense op om op God die barmhartige Vader te vertrou en dit skakel enige geloof in en vertroue op die hel heeltemal uit. Küng meen ook dat die gedagte van die hel met die Bybelse Godsbegrip in stryd is. Die God van vrede kan tog nie onvrede en onversoendheid verewig nie. Die God van genade en van liefde tot die vyand kan Hom tog nie vir ewig en ewig op sy vyande wreek nie. Dit is vir Küng ondenkbaar dat selfs God se wil en verpligting om te straf, nie altyd aan sy genade ondergeskik sal bly nie.

As Rooms-Katoliek kom hy egter nie so maklik van die tema af weg nie. Te veel kerkvaders het die temas van die oordeel, die verwerping en die hel bedink. Weliswaar het kerkvaders soos Origenes, Gregorius van Nyssa, Didimos, Diodorus van Tarsus, Theodorus van Mopsuestia en Hieronimus nie soos die Sinode van Konstantinopel in 543 'n ewigdurende hellestraf verdedig nie, maar die feit bly dat hulle aan 'n tydelik begrensde hel geglo het. Küng (1992:232-234) meen ook dat 'n mens aan God se geregtigheid sal moet twyfel indien alle mense op dieselfde wyse in die ewige saligheid sou indring. 'n Moordenaar kan tog sekerlik nie op dieselfde wyse die saligheid verdien as ander mense nie. So 'n moordenaar moet sekerlik eers deur God gelouter en gereinig word voordat hy in die saligheid kan deel. Om hierdie rede hou Küng tog nog aan die omstrede gedagte van die purgatorium (vagevuur) vas, maar gee daaraan die volgende inhoud:

Das Purgatorium des Menschen ist nicht ein spezieller Ort und auch keine spezielle Zeit. Es ist Gott selber im Zorn seiner verborgenen Gnade: Die purificatio ist die Begegnung mit dem Dreimalheiligen, sofern sie den Menschen richtet und läutert, aber dadurch auch befreit und erleuchtet, heilt und vollendet.

(Küng 1992:233) 
Die indruk kan maklik gewek word dat Küng ook soos Origenes die apokatástasis pánton - (die alversoening o a op grond van Rom 11:32) - voorstaan. Só 'n beskuldiging sou volgens Küng op 'n misverstand berus. Hy kan hierdie leer om 'n etiese en 'n dogmatiese rede nie aanvaar nie. Die alversoeningsleer ondergrawe die erns van die lewe en die verantwoordelikheid van die enkeling tot etiese beslissings. Hierdie leer weerspreek ook die soewereine vryheid van God. Nogtans verwerp Küng (1992: 236) Calvyn se gedagte van 'n praedestinatio gemina, 'n dubbele predestinasie waardeur sommiges tot saligheid en andere tot verdoemenis veroordeel word. Calvyn se leer word volgens hom deur God se algemene heilswil, sy barmhartigheid en sy liefde tot elke mens weerspreek. Nogtans meen Küng dat 'n mens in die lig van Paulus se teologie kwalik nie tot ' $n$ ander konklusie kan kom as om aan twee aspekte vas te hou nie: die mens se persoonlike verantwoordelikheid en God se genade. In die lig hiervan meen hy dat ' $n$ mens daarom eintlik maar net met 'n tweeledige vermaning moet volstaan: Moenie te seker wees van jou heil nie - en moenie aan God se genade perke probeer stel nie!

Wat ek regdeur hierdie artikel aan die orde probeer stel het is dat God nie net die Genadige en Barmhartige is nie, maar ook die Toornige en Strawwende. Aangesien die komende koninkryk met die vernietiging van sonde en die bose te make het, moet hierdie koninkryk met gerig en oordeel te make hê (Stock 1980:248). Juis wanneer 'n mens met die regverdigingsleer werk is dit 'n noodwendigheid dat die gerig van God bedink sal word. Selfs Walter Kreck (1961:124-125) het dit uitgewys dat die geloof in die regverdiging deur Jesus Christus, die verwagting van sy wederkoms tot gerig, as 'n noodwendigheid moet insluit. Daar kan baie vrae en onverklaarbaarhede oor die God van liefde wat straf bestaan — ja, daar kan saam met Nietzsche (1977:833; 1202-1203) gesê word dat dit op siele-waansin neerkom, maar ek kan nie anders as om saam met die Fin Lennart Pinomaa te sê:

Es kann nämlich nicht erklärt werden, wieso in Gott, der die Liebe ist, Verderben für seine Geschöpfe und richtende Abgründe sein können. Aber die Tatsache, daB der Mensch nicht einmal in seinen Gedanken Gott zu beherrschen vermag, zeigt, daß die einzig mögliche Lage des Menschen vor Gott die des Gehorsams und der Demut ist. Deswegen ist Gottes Zorn eine derjenigen Seiten im Gottesbild, die unser Gottesverhältnis lebendig erhalten, und aus diesem Grunde stellt der Zorn Gottes eine wesentliche Seite im christlichen Gottesbild dar. 
Wanneer ek die realiteit van die oordeel van God wil beklemtoon, beteken dit nie dat ek God as 'n genadelose tiran wil voorstel wat 'n behae daarin het om mense vir ewig te verdelg nie. So 'n gedagte laat hom in elk geval nie eenduidig vanuit die Skrif substansieer nie. Die Bybelse boodskap is té veelhoekig vir enige kategoriese standpunt; van welke aard ook al. Aan die een kant is 'n noodwendige alversoeningsleer dogmaties onhoudbaar, aangesien hierdie leer op 'n menslike ingrype in God se wil tot gerig neerkom. Aan die ander kant is die leer oor 'n ewige verdoemenis ook 'n dogmatiese bedenklikheid, aangesien dit op ' $n$ ingrype in God se wil tot genade neerkom. 'n Mens sal kwalik tot ' $n$ ander standpunt kan kom as om te sê ons weet nie of God se straf ewig gaan wees aldan nie. Wat ons wel weet is dat daar uitsprake is wat op 'n ewige verdoemenis wys en ander uitsprake wat weer op die teendeel wys. Wilfried Härle het daarom waarskynlik reg as hy sê:

Wenn wir beharrlich, verständlich und einladend die in Joh 3,16 exemplarisch zusammengefaßte Botschaft verkündigen, dann tun wir ganz gewiß auch der Welt einen besseren Dienst, als indem wir darüber nachdenken wie voll oder leer die Hölle sein wird oder mit welchem Härtegrad an Unglauben jemand im Jüngsten Gericht noch $>>$ durchkommen $<<$ kann.

(Härle 1990:65)

Dit het dus nie enige sin om oor die lot van ongelowiges te spekuleer nie. Dalk is God se genade groot genoeg om hulle te akkomodeer, en dalk nie. Ons weet dit eenvoudig nie. Wat ons wel weet is dat ons die verantwoordelikheid het om die evangelie te verkondig en om mense oor God se gerig te waarsku, en dat God wel regverdig oor almal sal oordeel. Vir hierdie standpunt vind ek steun by minstens Brunner (1960:464474), Ott (1973:466-471) en Berkhof (1973:553-556).

\section{DIE PREDIKING OOR DIE EINDOORDEEL VANDAG}

Karl Barth het in sy homiletiek (1986:32-72) daarop gewys dat prediking kerklike prediking is wat aan die openbaring en die kerk se belydenis gebonde is. Die wêreld mag daarom nie die omvang van die preektemas en die inhoud van die prediking bepaal nie - dit word deur Skrif en belydenis bepaal. 'n Mens sal ook moet toegee dat die stemming van die wêreld en die gedagtes van die wêreld tog op die kerk se prediking invloed het. Die goeie stryd wat egter gestry moet word is om te verseker dat die volle Goddelike boodskap gehoor sal word. Om hierdie rede lê die inhoud van die Bybel 'n 
verpligting op ons om ook oor die eindoordeel en al sy konsekwensies te preek. Die prediking moet daartoe bydra dat die wêreld die gerig van God herontdek. Wanneer dit gebeur, sal mense weer tot die besef kom dat ons voor die aangesig van 'n lewende God lewe en sal hulle hopelik in groter verantwoordelikheid en liefde lewe - juis dit wat ons in ons land so nodig het. Die erns van hierdie pleidooi word vir ons nêrens só treffend uitbasuin as in die monumentale musikale singedig van Georg Philipp Telemann ${ }^{10}$ (1762) nie. Hier word wreedaards en moordenaars, wat meen dat hulle met hulle wandade sal wegkom, met die volgende woorde gewaarsku:

Nein! Gott hat schon die Rachepfeile,
Den Tod der Mörder ausgesucht.
Ein Tag der Schrecken bricht herein,
Von Gnade voll und schwer von Pein,
Zum Fluche dem, der Gott geflucht,
Und seinen Gläubigen zum Heile.

Weens die realiteit en verskriklikheid van die eindoordeel, moet hierdie tema in ons dag weer die aandag kry wat dit verdien, sodat Jesus Christus nie dalk eendag vir ons moet sê wat Hy in Telemann se lied vir die goddeloses sê nie:

Hinweg von meinem Angesichte!

Ihr Feinde Gottes, seid verdammt!

Euch martre ewig eu'r Gewissen

Und Satan, der euch leiten müssen,

Und jene Hölle, die dort flammt.

Daar moet toegegee word dat die prediking oor die eindoordeel in ons dag nie 'n maklike taak is nie. Die algemene mishae in 'n God wat straf - en dalk nog vir ewig straf - asook die veelhoekigheid en selfs weersprekendheid van die Bybelse gegewens maak dit gewis nie maklik nie. Die enigste oplossing is om die totale boodskap van die Skrif, soos saamgevat in die verkillende belydenisskrifte van die kerk, te verkondig: die vrees vir en die vreugde aan die eindoordeel, God se genade en God se toorn, Jesus wat nie wil veroordeel nie en Christus wat eendag op grond van die werke gaan oordeel en verstoot, die maatstaf van die geloof en die maatstaf van die werke, die moontlikheid van ' $n$ hel en die onwaarskynlikheid van ' $n$ hel, predestinasie en bekering en wat ook al nog uit die Skrif aangebied mag word. Tog sal 'n mens nie anders kan om as 'n 
Protestant altyd weer na die sentrum van ons geloof, die regverdigingsleer, terug te gryp nie. Sonder ' $n$ voortdurende terugval op die hart van die evangelie, sal 'n mens lidmate net al meer en meer verwar. Die regverdigingsleer, die 'genade op grond van die kruis alleen, sal egter dwaasheid bly solank ons lidmate nie leef met die wete dat wysheid op die 'vrees van die Here' (Spreuke 1:7) neerkom nie. Die prediker het nie die taak om wêreldse vrese aan te jaag nie - daarvan het ons genoeg; hy het net die taak om vrees vir Hom aan te wakker wat tans in hierdie wêreld en eendag aan die einde van hierdie wêreld gaan handel. Hy moet mense daarom nie laat vrees vir dit wat kom nie, maar eerder vir Hom wat kom - ja, Hy wat in sy liefde kom om dié te red wat in Hom glo en volg, en vir dié wat Hom nie wil ken en volg nie te sê: ek ken julle nie, en het daarom nie vir julle plek voorberei nie.

\section{Gottesfurcht ist ein Hörerfolg (Bohren 1986:265).}

\section{Endnotas}

1 Hy het kort tevore in ' $n$ uitleg van Psalm 71 die advent nog beskryf as 'n koms in Iudicio serveritatis et vindicta eterna (WA 3, 462, 6).

2 Een rede hoekom die geweldige vrees vir die eindoordeel verdwyn het is dat die Rooms Katolieke Kerk dit nie meer as middel kan gebruik om mense na hom terug te dwing as alleensaligmakende kerk nie (Lochman 1993:79).

3 Die groot illusie waarme Hirsch gelewe het was dat hy die moderne waarheidsbewussyn as die verlenging van die Lutherse teologie gesien het (kyk Bayer 1991:202).

4 Die oorspronklike uitspraak gaan egter op Schiller terug. In sy gedig van 1786 Resignation, kom 'n mens vir die eerste maal hierdie uitspraak tee (vir volledigheid kyk: Bayer 1991:204).

5 Ek (Van Wyk 1993) en Lochman (1993) het onafhanklik van mekaar eh onafhanklik van Moltmann ook al dieselfde gedagte probeer bevorder. Ons het elkeen vanuit sy eie verwysingsraamwerk die gedagte van die Appellationsgericht uitgelig.

6 Dit behoort duidelik te wees dat Pannenberg ook nog steeds met 'n 'doen-en-gevolgsamehangsteorie' werk. Ook hy sal van die eksegetiese resultate insake die wysheidsliteratuur, soos deur Preub aangetoon, moet kennis neem.

7 Op grond van 1 Korinthiërs 3:10-15 het die leer van die reinigingsvuur of die louteringsvuur in die begin van die 3e ceu by die Alexandrynse tooloè ontstan. Origenes het hierdie leer volledig uitgewerk en dit is deur Cyprianus en die Koppodosiese vaders van die 40 eeu oorgeneem. Hierdie leer is egter later dour Chrysostomus bestry weens die verbinding wat dit met die apokatastasisleer van Origenes ontwikkel het. Hiendie leer het gevolglik in die Ooste verdwyn, terwyl dit in die Weste, danksy Cypriamus, voortgelewe het. Hierdie leer is iots anders as die leer 
oor die vagevuur wat handel oor die weg van die siel tussen dood en wêreldeinde, en wat eers in die Middeleeue ontstaan het. Dit is egter belangrik om daarop te wys dat Luther (WA 1, 555, 6 [1518]) die gedagte van 'n vagevuur aanvanklik goedgepraat het. Later het Luther (BSELK 659, 5) en Calvyn (Inst III, 5, 6) hierdie leer verwerp omdat die Roomse Kerk in hulle leerontwikkeling sover gegaan het om te beweer dat mense deur boete en aflaat die lot van die afgestorwenes kan verander, terwyl dit tog duidelik is dat 'n mens se lot slegs deur Christus bepaal word.

Dit is verder interessant dat die Konsilie van Lyon (1274), wat die leer oor die vagevuur dogmaties vasgelê het, wel die moontlikheid van die voortbestaan van die siel na die dood en die verbetering van die sedelike toestand van hierdie siele geopper het, maar dit nie as leer verdedig het nie. Die Konsilie van Trente (1580), wat die leer oor die vagevuur bekragtig het, het weer net die bestaan van 'n purgatorium en die toelaatbaarheid yan voorbidding vir afgestorwenes verdedig.

8 Die voorstelling van die eindoordeel as Dies irae, dies illa gaan volgens Küng terug na pous Pius V, 'n vroeëre Roomse grootinkwisiteer, wat hierdie woorde in 1570 in die dodemis ingedra het. Lochman (1993:79) verskil van Küng en meen dat hierdie woorde van die komponis Thomas van Celano afkomstig is.

9 Pous Paulus VI het sy ensiklikum oor die seksuele moraal, Humanae vitae, op die minderheidsverslag van kardinaal Ottaviani gebasseer, met die argument dat hy en sy groep die enigste teoloë is wat getrou is aan die ortodokse moraalleer. Die teoloe wat die meerderheidsverslag (wat voorbehoedmiddels goedkeur) opgestel het en die lidmate wat hulle sou volg, is met ewige pyniging in die hel gedreig.

${ }^{10}$ Die musiek is van Telemann terwyl die gedig self van Christian Wilhelm Alers is.

\section{Literatuurverwysings}

Amelung, E 1984. s v 'Gericht Gottes: Neuzeit und ethisch'. TRE Band XII.

Barth, K [1966] 1986. Homiletik: Wesen und Vorbereitung der Predigt. Zurich: Theologischer Verlag.

Bayer, O 1991. Das Letzte Gericht als religionsphilosophischen Problem. NZSTh 33, 199-210.

Berkhof, H 1973. Christelijk Geloof. Nijkerk: Callenbach.

Bohren, R 1986. Predigtlehre. München: Kaiser.

Brunner, E 1960. Dogmatik, Band III. Zürich: Zwingli-Verlag.

Brunner, P 1966. > Rechtfertigung < < heute, in PRO ECCLESIA: Gesammelte Aufsätze zur dogmatischen Theologie, Band 2, 122-140. Berlin: Uitgewer onduidelik.

Calvyn, J [1559] 1992. Institusie van die Christelike Godsdiens, Boek 4. Potchefstroom: CJBF.

- [s a]. Het gepredikte Woord: Preken van Johannes Calvijn. Vertaald door Douma, J en Van der Vegt, W H. Deel III. 2e Druk. (Preek oor 2 Tess 1:8-10= 193-207). Franeker: Wever.

$\mathrm{CR}=$ Corpus Reformatorum 
Denzinger, H (Hrsg) [1854] 1960. Enchiridion symbolorum, definitionum et declarationum et rebus fidei et morum. 31. Ausg. Freiburg: Herder.

Douma, J 1990. Ethiek en recht. Kampen: Van den Berg. (Ethische Bezinning 15.)

Graffmann, H 1936. Das Gericht nach den Werken im Matthäusevangelium, in Theologische Aufsätze: Karl Barth zum 50. Geburtstag, Hrsg v E Wolf, 124-135. München: Kaiser.

Grundel, J 1981. Strafen und Vergeben, in Christlicher Glaube in moderner Gesellschaft. Teilband 13, 123-160. Freiburg: Herder.

Härle, W 1990. Die Rede von der Liebe und vom Zorn Gottes. Beiheft 8 der ZThk, 50-69.

Hegel, G W F [1821] 1970. Grundlinien der Philosophie des Rechts. Frankfurt: Suhrkamp. (Werke Bd. 7.)

Heidler, F 1983. Die biblische Lehre von der Unsterblichkeit der Seele; Sterben,.Tod, ewiges Leben im Aspekt lutherischer Anthropologie. Göttingen: Vandenhoeck.

Hirsch, E 1923. Das Gericht Gottes. ZsTh 1, 199-226.

Irenaeus [1857]. Adversus haeresus. Canterbury: Uitgawe W Harvey.

Kaiser, O 1993. Der Gott des Alten Testaments- Theologie des AT 1: Grundlegung. Göttingen: Vandenhoeck.

Koch, K 1955. Gibt es en Vergeltungsdogma im AT? ZThK 52, 1-42.

Kreck, W 1961. Die Zukunft des Gekommenen. München: Kaiser.

Kuitert, H 1992. Het algemeen betwijfeld Christelijk geloof: Een herziening. 12e Druk. Baarn: Ten Have.

Küng, H 1992. Credo: Das Apostolische Glaubensbekenntnis Zeitgenossen erklärt. München: Piper.

Lochman, J-M 1993. Angst vor dem Jüngsten Gericht? ThZ 49, 77-88.

Lohse, E 1988. Theologische Ethik des Neuen Testaments. Stuttgart: Kohlhammer.

Luther, M 1833vv. WA = Kritische Gesamtausgabe: Weimarer Ausgabe.

Mbiti, J [1969] 1985. African religions and philosophy. Suffolk: Richard Clay. Moltmann, J [1964] 1977. Theologie der Hoffnung. 10. Aufl. München: Kaiser. 1989. Der Weg Jesu Christi: Christologie in messianischen Dimensionen. München: Kaiser.

Nietzsche, Fr 1977. Zur Genealogie der Moral. 2. Abhandlung: Schuld, Schlechtes Gewissen und Verwandtes, und - Der Antichrist. Werke in drei Bände, Band 2. Hrsg v K Schlechta. Darmstadt: Wissenschaftliche Buchgesellschaft.

Ott, H 1973. Die Antwort des Glaubens: Systematische Theologie in 50 Artikeln. Stuttgart: Kreuz.

Pannenberg, W 1993. Systematische Theologie, Band 3. Göttingen: Vandenhoeck. 
Peters, A 1967. Kirche und Welt im Lichte des eschatologischen Richters- und Erretterhandelns Gottes. NZSTh 9, 275-313.

- 1984. Rechtfertigung. Gütersloh: Mohn. (HSt Band 12.)

1991. Kommentar zu Luthers Katechismen, Band 2: Der Glaube. Göttingen: Vandenhoeck.

Pinomaa, L 1940. Der Zorn Gottes: Eine dogmengeschichtliche Übersicht. ZsTh 17, 587-614.

Preuß, H D 1991. Theologie des Alten Testaments, Band 1. Stuttgart: Kohlhammer.

Scmid, H H 1968. Gerechtigkeit als Weltordnung. München: Kaiser.

Schnackenburg, R 1993. Die Person Jesu Christi im Spiegel der vier Evangelien. Freiburg: Herder.

Stock, K 1980. Gott der Richter: Der Gerichtsgedanke als Horizont der Rechtfertigungslehre. EvTh 40, 240-256.

Stuhlmacher, P 1989. Der Brief an die Römer. Göttingen: Vandenhoeck. (NTD Band 6.)

Van der Vegt, W H [s a]. Inleiding tot: Het gepredikte Woord: Preken van Johannes Calvijn. Vertaald door Douma, J en Van der Vegt, W H. Deel 1. 2e Druk. Franeker: Wever.

Von Rad, G 1970. Weisheit in Israel. Neukirchen-Vluyn: Neukirchener.

Van Wyk, I W C 1993. Die eindoordeel: Monster of geraamte? Die Hervormer 15 Februarie 1993, bl 5 en 6.

Westermann, C 1978. Theologie des Alten Testaments in Grundzügen. Göttingen: Vandenhoeck. (ATD Band 6.)

Wilckens, U 1978. Der Brief an die Römer (Röm 1-5). Neukirchen-Vluyn: Neukirchener. (EKK VI/1.)

Zimmerli, W 1975. Grundriß der alttestamentlichen Theologie. 2. Erw. Aufl. Stuttgart: Kohlhammer. 